\title{
Cyclic thrombocytopenia: A case report
}

\section{Siklik trombositopeni: Olgu sunumu}

\author{
Abdullah Şumnu1, Reyhan Diz-Küçükkaya² \\ ${ }^{1}$ Department of Internal Medicine, İstanbul University, İstanbul Medical Faculty, İstanbul, Turkey \\ ${ }^{2}$ Division of Hematology, Department of Internal Medicine, Istanbul University, Istanbul Medical Faculty, Istanbul, Turkey
}

\begin{abstract}
Cyclic thrombocytopenia (CTP) is a rare disorder characterized by periodic decreases and increases in platelet levels. Each cycle usually spans a period of 3-5 weeks. Clinical features are similar to those of idiopathic thrombocytopenic purpura (ITP), so patients are frequently misdiagnosed as having ITP. However, CTP usually does not respond to most treatments used in ITP such as corticosteroids, splenectomy and intravenous immunoglobulin. In this case report, we present a 33-year-old woman with CTP misdiagnosed as ITP. (Turk J Hematol 2010; 27: 196-9)
\end{abstract}

Key words: Cyclic thrombocytopenia, idiopathic thrombocytopenic purpura, hepatitis B, case report

Received: November 4, 2008

Accepted: April 8, 2009

\section{Özet}

Siklik trombositopeni (ST) trombosit seviyelerinde periyodik düşüs ve yükselmeler ile karakterize olan nadir görülen bir hastalıktır. Bir siklusun uzunlụ̆u genellikle 3-5 hafta arasındadır. Hastalığın klinik özellikleri idiyopatik trombositopenik purpura (ITP) ile benzerlik gösterdiğinden hastalara sı olarak yanlışlıkla ITP tanısı koyulmaktadır. Ancak ST genellikle kortikosteroidler, splenektomi ve intravenöz immünoglobulin gibi ITP tedavilerine yanıt vermez. Bu olgu sunusunda öncesinde ITP tanısı ile takip edilmiş 33 yaşında bir kadın hasta sunuyoruz.

(Turk J Hematol 2010; 27: 196-9)

Anahtar kelimeler: Siklik trombositopeni, idiyopatik trombositopenik purpura, hepatit B, olgu sunusu

Geliş tarihi: 4 Kasım 2008

Kabul tarihi: 8 Nisan 2009 


\section{Introduction}

Cyclic thrombocytopenia (CTP) is a rare disorder characterized by periodic decreases and increases in platelet levels [1]. Each cycle usually spans a period of 3-5 weeks. The platelet counts fluctuate by a large scale on a periodic basis. In the reported cases, the median nadir and peak platelet counts are $10 \times 10^{9} / \mathrm{L}$ (range $1-90 \times 10^{9} / \mathrm{L}$ ) and $330 \times 10^{9} / \mathrm{L}$ (range $72-2300 \times 10^{9} / \mathrm{L}$ ) [2]. Rebound thrombocytosis (> 500x $\left.10^{9} / \mathrm{L}\right)$ without therapy is an important and distinctive feature for CTP. Women are affected more than men. Although some cases have been reported in myeloproliferative diseases, most cases are idiopathic $[3,4]$. The pathophysiology is unclear. Some potential mechanisms are autoimmune platelet destruction, megakaryocytic hypoplasia/aplasia, and infectious and hormonal etiology. Clinical presentation is not different from that of idiopathic thrombocytopenic purpura (ITP). Some patients are asymptomatic. Patients may experience easy bruising, gingival bleeding, recurrent epistaxis, menorrhagia, and hematuria. They may present with more serious bleeding like gastrointestinal or central nervous system hemorrhages. In most cases, CTP is not considered as a differential diagnosis so patients are diagnosed and treated as having ITP. CTP usually does not respond to most treatments used in ITP such as corticosteroids, splenectomy and intravenous immunoglobulin (IVIG). In this condition, a diagnosis of CTP should be considered. Close observation without treatment seem to be the best management if clinically permissible. There are some case reports with complete remission after hormonotherapy (danazol and sex hormones) [5-8].

\section{Case Report}

A 33-year-old woman was admitted to the hospital in April 2006 with purpura. Initial complete blood cell count showed thrombocytopenia (platelet count: $6 \times 10^{9} / \mathrm{L}$ ), a mild iron deficiency anemia and normal white blood cell count. After making an initial diagnosis of ITP, the patient received $1 \mathrm{mg} / \mathrm{kg} /$ day methylprednisolone for 1 week, $1 \mathrm{~g}$ /day methylprednisolone for 3 days and finally $1 \mathrm{~g} / \mathrm{kg}$ IVIG therapy. There was no response. Then, the platelet count began to increase spontaneously and reached $750 \times 10^{9} / \mathrm{L}$ in the third week. After 45 days, when she was admitted to the hospital for the second time with purpura, she was administered $2 \mathrm{mg} / \mathrm{kg} /$ day methylprednisolone. No response was achieved. The platelet count reached $800 \times 10^{9} / \mathrm{L}$ again without therapy. Three months later, when the third purpuric attack occurred, splenectomy was suggested, and the patient was admitted to our Hematology Department. Oral informed consent was obtained from the patient.

She was married, with no children, and was working in a hair salon. Her hepatitis B surface antigen was positive. Her physical examination revealed petechiae and ecchymoses on her body and hemorrhagic bullae in the oral mucosa. There was no hepatomegaly, splenomegaly or lymphadenomegaly. Signs of Cushing syndrome were seen and she was still taking $48 \mathrm{mg}$ methylprednisolone per day orally.

Laboratory investigations revealed: platelet: 180x109/L, hemoglobin: $10.7 \mathrm{~g} / \mathrm{dl}$, hematocrit: $32 \%$, MCV: $74 \mathrm{fl}$, ferritin: $3 \mathrm{ng} / \mathrm{ml}$, SGOT: $240 \mathrm{IU} / \mathrm{ml}$, SGPT: $280 \mathrm{IU} / \mathrm{ml}$, hepatitis B surface antigen (HBsAg): +, and HBV-DNA: + . Peripheral blood smear showed hypochromia, microcytosis, and normal leukocyte differentiation with no abnormal cells, and the platelets had normal morphology. We tapered and then stopped the corticosteroid dose, administered lamivudine for hepatitis $\mathrm{B}$, and added oral iron therapy for iron deficiency anemia. We followed the patient every week with complete blood count. The

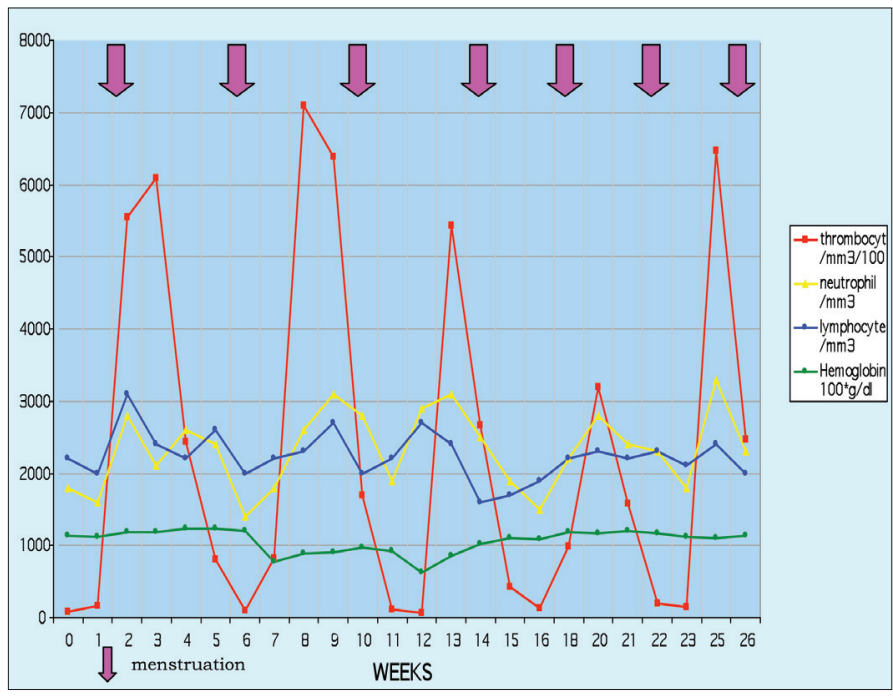

Figure 1. Platelet counts of the patient showed a cyclic pattern. Interestingly, lymphocyte and neutrophil counts also showed a cyclic pattern without neutropenia. Platelet cycles occurred in synchrony with menstruation. It has been thought that the decrease in hemoglobin level was related to hypermenorrhea 
platelet count and also neutrophil and lymphocyte count showed cyclic decreases over a period of five weeks (Figure 1). Anemia as a consequence of thrombocytopenia and menorrhagia contributed to the clinic picture. The diagnosis of CTP was made. Medroxyprogesterone acetate was initiated to control hypermenorrhea after gynecological consultation. Tranexamic acid was also added to control bleeding symptoms when the patient had nadir platelet count. After we accumulated data revealing that the patient had thrombocytopenia every five weeks, we started to use oral contraceptives and tranexamic acid to manage the patient's menstruation. With this therapy, hypermenorrhea was controlled, and the patient did not experience any major bleeding during the two-year follow-up.

\section{Discussion}

In this case report, a 33-year-old woman with CTP misdiagnosed as ITP was presented. She had severe thrombocytopenia with bleeding symptoms followed by thrombocytosis. She received corticosteroids and IVIG therapy with no response. Because she had rebound thrombocytosis, we suspected the diagnosis of CTP. The observation of this patient with weekly platelet counts showed cyclic fluctuation, proving the CTP diagnosis.

The pathophysiology of CTP is unclear. Some potential mechanisms are autoimmune platelet destruction, megakaryocytic hypoplasia/aplasia, and infectious and hormonal etiology. There are some reported cases that respond well to hormonotherapy, especially to danazol. It has been shown that most female CTP patients had low platelet counts during menstruation. It has also been shown that hysterectomy and bilateral salpingo-oophorectomy did not affect platelet fluctuation in those patients [2].

In our case, platelet cycles occurred in synchrony with menstruation (Figure 1). Because our patient had hypermenorrhea causing anemia, we used oral contraceptives for controlling menstruation. Although the oral contraceptive drug did not affect platelet fluctuations, it helped to manage the time of menstruation. We also used tranexamic acid to decrease bleeding symptoms.

The association between CTP and infections has not been described. To date, CTP had been report- ed only in dogs via Ehrlichia platys $[9,10]$ and it was documented to resolve after antibiotherapy [11]. However, there is not yet any data about human ehrlichiosis causing CTP.

Considering that HBsAg in our patient was positive, the association between CTP and hepatitis B needs to be studied. There are some case reports about isolated thrombocytopenia in the course of acute or chronic hepatitis B [12,13]; however, a CTP-hepatitis B association is unknown.

In conclusion, CTP is a rare disorder, but in patients with ITP who have not responded to several treatments and have rebound thrombocytosis, a diagnosis of CTP should be considered.

\section{Conflict of Interest}

No author of this paper has a conflict of interest, including specific financial interests, relationships, and/or affiliations relevant to the subject matter or materials included in this manuscript.

\section{References}

1. Balduini CL, Carlo Stella C, Rosti V, Bertolino G, Nons P, Ascari E. Acquired cyclic thrombocytopenia-thrombocytosis with periodic defect of platelet function. $\mathrm{Br} \mathrm{J}$ Haematol 1993;85:718-22.

2. Go RS. Idiopathic cyclic thrombocytopenia. Blood Rev 2005;19:53-9.

3. Steensma DP, Harrison CN, Tefferi A. Hydroxyureaassociated platelet count oscillations in polycythemia vera: a report of four new cases and a review. Leuk Lymphoma 2001;42:1243-53.

4. Abe Y, Hirase N, Muta K, Okada Y, Kimura T, Umemura T, Nishimura J, Nawata H. Adult onset cyclic hematopoiesis in a patient with myelodysplastic syndrome. Int J Hematol 2000;71:40-5.

5. Tomer A, Schreiber AD, McMillan R, Cines DB, Burstein SA, Thiessen AR, Harker LA. Menstrual cyclic thrombocytopenia. Br J Haematol 1989;71:519-24.

6. Rocha R, Horstman L, Ahn YS, Mylvaganam R, Harrington WJ. Danazol therapy for cyclic thrombocytopenia. Am J Haematol 1991;77:140-3.

7. Kashyap R, Choudhry VP, Pati HP. Danazol therapy in cyclic acquired amegakaryocytic thrombocytopenic purpura: a case report. Am J Haematol 1999;60:225-8.

8. Kuayama J, Take H, Matsumoto S, Nakajima T, Sugase T, Hata A, Hanada M, Nakagawa K. Synchronous fluctuation of interleukin- 6 and platelet count in cyclic thrombocytopenia and thrombocytosis. Intern Med 1995;34:636-9. 
9. Waner T, Leykin I, Shinitzky M, Sharabani E, Buch H, Keysary A, Bark H, Harrus S. Detection of plateletbound antibodies in beagle dogs after artificial infection with Ehrlichia canis. Vet Immunol Immunopathol 2000;77:145-50.

10. Wong SJ, Thomas JA. Cytoplasmic, nuclear, and platelet autoantibodies in human granulocytic ehrlichiosis patients. J Clin Microbiol 1998;36:1959-63.
11. Chang WL, Su WL, Pan MJ. Two-step PCR in the evaluation of antibiotic treatment for Ehrlichia platys infection. J Vet Med Sci 1997;59:849-51.

12. Ozaras R, Celik AD, Kisacik B, Mert A, Aki H, Ozturk R, Tabak F. Acute hepatitis B and isolated thrombocytopenia. J Clin Gastroenterol 2003;37:87-8.

13. Romero R, Kleinman R. Thrombocytopenia associated with acute hepatitis B infection. Pediatrics 1993;91:150-2. 